\author{
Vasant Chabukswar and Sanjay Bhavsar
}

\title{
SYNTHESIS AND CHARACTERIZATION OF ORGANICALLY SOLUBLE AND ELECTRICALLY CONDUCTING ACIDS DOPED POLYANILINE
}

\author{
Department of Chemistry, N owrosjee Wadia College (Affiliated to Pune University), Pune-411001, \\ M aharashtra, India
}

Received: February 02, 2010 / Revised: May 12, 2010 / Accepted: September 07, 2010

(C) Chabukswar V., Bhavsar S., 2010

\begin{abstract}
Emeraldin salt of polyaniline was synthesized by chemical oxidative polymerization method; this salt is soluble in common organic solvents. The obtained results are discussed with reference to lactic acid doped polyaniline. It has been observed that acrylic acid doped polyaniline is comparatively more soluble than polyaniline doped with lactic acid in common organic solvent such as $m$-cresol, NMP ( $N$-methyl pyrrolidinone), DMSO, DMF, etc. The acrylic acid doped polymer prepared using lactic acid is comparatively more soluble in m-cresol and NMP than the polyaniline without acrylic acid. UV-Visible spectra for acrylic acid doped polyaniline reveals the coil conformation at higher wavelength along with sharp peak. This indicates that the conductivity of acrylic acid doped polyaniline is higher than that of polyaniline without acrylic acid. A broad and intense band at $3400-3300 \mathrm{~cm}^{-1}(\mathrm{~N}-\mathrm{H}$ stretching $)$ and $1120-1225 \mathrm{~cm}^{-1}$ accounts for higher degree of doping and protonation of amine and imine $\mathrm{N}$-atom. These results are well supported by the conductivity measurement - the conductivity of acrylic acid doped polyaniline is higher than in case of polyaniline without acrylic acid.
\end{abstract}

Keywords: polyaniline, solubility, conductivity, acrylic acid.

\section{Introduction}

Polyaniline is an important conjugated polymer. It is relatively easy to prepare. A major problem concerned to its successful utilization are its poor mechanical properties like solubility and conductivity in common organic solvents, however nowadays much progress has been done in this field. This improvement is done by using different organic acids as dopant or stabilizer [1-3].

The dopant is introduced by simple secondary doping or by blending the polymer with doping species, such as acrylic acid.

This chemical oxidative polymerization method yields polymer having better solubility in common organic solvents such as $m$-cresol, NMP, DMF, etc. Such polymer also has better conductivity, which is very important form application point of view since conductivity of polymer changes under exposure to ammonia vapors or other gases like $\mathrm{H}_{2} \mathrm{~S}$.

In this work we report the chemical oxidative synthesis of electrically conducting and organically soluble acid doped polyaniline. This is the comparative study of polyaniline with and without acrylic acid, lactic acid being used as a stabilizer acid.

\section{Experimental}

The proliferation of monomer aniline was carried out by the usual method, i.e. oxidative polymerization method. All the chemicals used were AR grade and purified by distillation before use. The oxidizing agent used was ammonium persulphate and the acid used was lactic acid.

The oxidizing agent was added dropwise to an acidified solution of monomer under constant stirring at low temperature between 273-278 K. The acrylic acid doped polymer was synthesized by the addition of $0.68 \mathrm{ml}$ of acrylic acid to the reaction mixture containing Aniline and lactic acid prior to addition of oxidizing agent. After complete addition of oxidizing agent the reaction mixture was kept under constant stirring for $24 \mathrm{~h}$. A dark green precipitate of the polymer was isolated by filtration and drying in the oven till constant weight.

The UV-Vis spectra of the polymer solution in $m$-cresol and NMP were recorded by using double beam spectrophotometer in the range of 350-900 nm.

The IR spectra of the polymer were taken on FT-IR spectrophotometer within the range of 400$4000 \mathrm{~cm}^{-1}$. For recording IR spectra $\mathrm{KBr}$ pellets of the polymer were prepared in the ratio of 150:1 mg. Finally the conductivity of the sample (pellet) was measured with the help of a two-probe method. 


\section{Results and Discussion}

\subsection{UV-Vis Spectra}

The electronic absorption spectra of the lactic acid doped polymer synthesized in the presence of acrylic acid recorded by dissolving polymers $(5 \% \mathrm{w} / \mathrm{v})$ in $m$-cresol and NMP are depicted in Fig. 1.

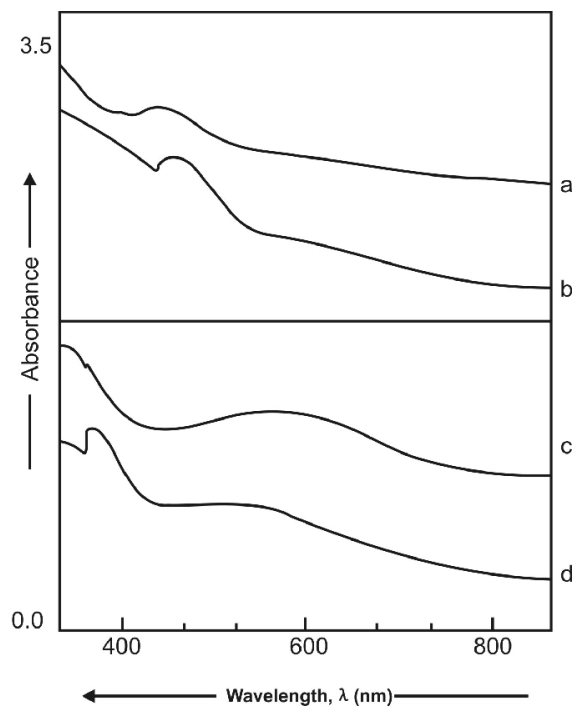

Fig. 1. UV-Visible spectra of acrylic acid and lactic acid doped polyaniline: lactic acid doped polyaniline (a); acrylic acid doped polyaniline in $m$-cresol (b); lactic acid doped polyaniline (c) and acrylic acid doped polyaniline in NMP (d)

Optical properties of conducting polymers are important for development and understanding of basic structures of the material. The conjugation in the polymers is characterized by their electronic spectra, thus spectroscopy is a powerful probe for characterization of the electronic transitions that occur in the conducting polymers [4-5].

UV-Vis spectra of the polymer doped with acrylic acid in the presence of lactic acid and that doped without acrylic acid was recorded by dissolving these polymers in $\mathrm{m}$-cresol and NMP. The spectral features observed in the figure reveal the enhanced solubility of the acrylic acid doped polymer, which is $70 \%$ soluble, in comparison with the lactic acid doped polymer, which is $\sim 40 \%$ soluble in each solvent. This can be attributed to the presence of a greater number of charges on the polymer chain in the acrylic acid doped polymer due to hydrogen bonding between solvent and polymer chain.

The optical spectra of the polymers show appreciable changes in $\mathrm{m}$-cresol and NMP. The sharp intense peak $588 \mathrm{~nm}$ in NMP can be assigned to the localized polorons, which are characteristic of the protonated polyaniline together with the extended tail representing the conducting forms of the polymer [6-7].
The intensity of the peak $\sim 406 \mathrm{~nm}$ is greater in acrylic acid doped polymer. This implies that doping is restored in the $m$-cresol medium apart from the solute - solvent interaction due to its polar nature, which contributes towards the expansion of the coil form of the polymer and hence the solubility; further extended tail at higher wavelength depicts that $m$-cresol not only serves as a solvent, but also acts as an efficient secondary dopant [8-9].

In the presence of NMP as a solvent the peak is observed at $559 \mathrm{~nm}$ representing the resulting emeraldin form of the polymer. As NMP is a highly polar solvent, interaction between solute and solvent is likely to be stronger than in m-cresol medium. The carbonyl group present in NMP molecule would try to form $\mathrm{H}$-bond of the $-\mathrm{COOH}$ group of a dopant or that present on the $\mathrm{N}$ atom of the polymer chain.

\subsection{IR Spectra}

The IR spectra of the lactic acid and acrylic acid doped polymer are given in Fig. 2 and characteristic peak locations related to the corresponding chemical bonds are listed in Table 1. However a remarkable difference is observed in the IR spectra in terms of specific bands and shifts in the two polymers. The broad and intense peak at $3300-3100 \mathrm{~cm}^{-1}$ and $1151 \mathrm{~cm}^{-1}$ in acrylic acid doped polymer accounts for the higher degree of protonation of amine and imine nitrogen's but the peaks observed in lactic acid doped polymer polyaniline is comparatively sharp and narrow, indicating lower degree of protonation and doping. Since both polymers exist in conducting polymer [10-12]

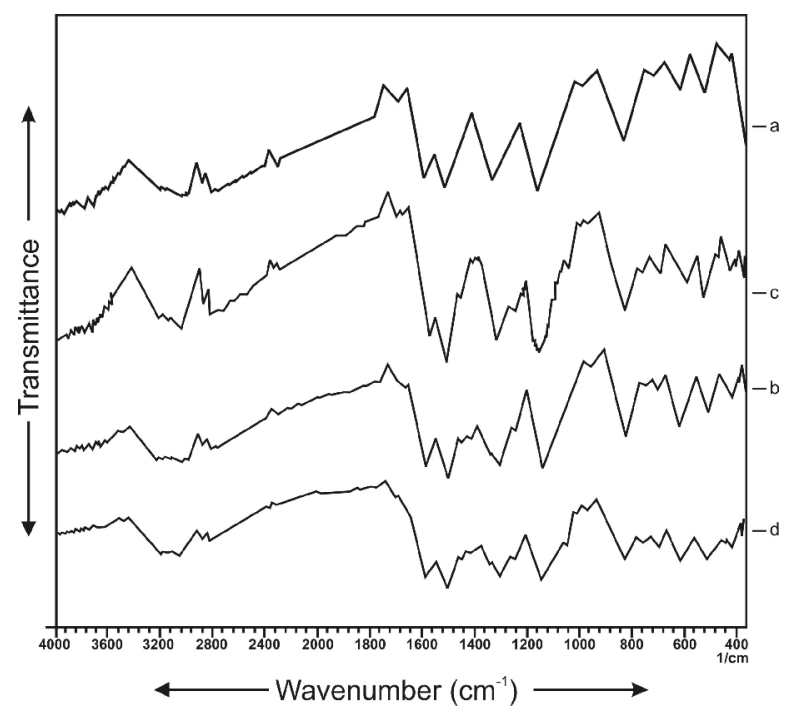

Fig. 2. FTIR absorption spectra of acrylic acid and lactic acid doped polyaniline: lactic acid doped polyaniline (a); lactic acid doped polyaniline expose to ammonia (b); acrylic acid doped polyaniline (c) and acrylic acid doped polyaniline expose to ammonia (d) 
this can be attributed to breaking up of a large number of inter chain $\mathrm{H}$-bonds that arise due to the addition of acrylic acid since it acts as a pseudo protonic acid and can coordinate with imine $\mathrm{N}$ atom of the polymer chain which results in disaggregation of the polymer chain and hence in its crystallinity.

The presence of a sharp peak at $2887 \mathrm{~cm}^{-1}$ indicates $\mathrm{C}-\mathrm{H}$ stretching vibration of acrylic acid and $\mathrm{C}-\mathrm{H}$ stretching frequency of $\mathrm{CH}_{3}$ group of aniline, but the peaks obtained from lactic acid doped polymer are weak and broad. A strong and intense peak at $1579 \mathrm{~cm}^{-1}$ in acrylic acid doped polymer is observed indicating quenoid ring stretching frequency; along with this peak another peak is observed at $1500 \mathrm{~cm}^{-1}$ indicating benzenoid ring stretching vibration. Benzenoid and quinoide bands are observed at $1500 \mathrm{~cm}^{-1}$ and $1579 \mathrm{~cm}^{-1}$. They are comparatively broad, weak and shifted to the lower wave number. Spectral intensity of these bands is comparatively typical of highly doped emaraldine salt form of polymer. The presence of a weak peak at $1700 \mathrm{~cm}^{-1}$ indicates non protonated $-\mathrm{COOH}$ group.

A broad peak at $1249 \mathrm{~cm}^{-1}$ of lactic acid and at $1247 \mathrm{~cm}^{-1}$ of acrylic acid doped polymer indicates aromatic $\mathrm{C}-\mathrm{N}$ stretching frequency. When the polymer is exposed to ammonia vapor it reveals differences in specific bands, which are more significant in acrylic acid doped polymer compared to lactic acid doped polymer. In case of ammonia exposure the peak at $3240 \mathrm{~cm}^{-1}$ is shifted to lower frequency at $3190 \mathrm{~cm}^{-1}$, which indicates that the doping level is maintained in the sample even after exposing to ammonia vapors, but in case of lactic acid doped polymer exposed to ammonia vapor slight increase in stretching frequency is observed [13-14].

The peak at $3260-3190 \mathrm{~cm}^{-1}$ is broadened indicating the oxidation of nitrogen of the polymer chain. The peak at $1579 \mathrm{~cm}^{-1}$ is slightly shifted to upper field, i.e. $1587 \mathrm{~cm}^{-1}$ in acrylic acid. The doped polymer exposed to ammonia vapor indicates the increase in the quinoid form. The peak at $1141 \mathrm{~cm}^{-1}$ and $1151 \mathrm{~cm}^{-1}$ observed indicates that the doping is maintained by free acrylic acid molecule.

\subsection{Conductivity}

The obtained results are well supported by the conductivity data obtained for both PNETA depicted in Table 2. The conductivity of acrylic acid doped polyaniline seems to increase upon exposure to ammonia vapours. This can be attributed to the presence of large concentration of COO-ions serving as dopant along with few lactic acid

FTIR bands for acrylic acid and lactic acid doped polyaniline

Table 1

\begin{tabular}{|c|c|c|c|l|}
\hline $\begin{array}{c}\text { Polyaniline } \\
\text { (lactic } \\
\text { acid), } \mathrm{cm}^{-1}\end{array}$ & $\begin{array}{c}\text { Polyaniline } \\
\text { (acrylic } \\
\text { acid), } \mathrm{cm}^{-1}\end{array}$ & $\begin{array}{c}\text { Polyaniline } \\
\text { (acrylic acid, } \\
\mathrm{NH}_{3} \text { exposed), } \\
\mathrm{cm}^{-1}\end{array}$ & $\begin{array}{c}\text { Polyaniline } \\
\text { (lactic acid, } \\
\mathrm{NH}_{3} \text { exposed), } \\
\mathrm{cm}^{-1}\end{array}$ & \multicolumn{1}{|c|}{ Peak assignment } \\
\hline $707-603$ & 698 & $617-696$ & $617-702$ & Out of plane C-H bending vibration \\
\hline 817 & 825 & 825 & 824 & Para-disubstituted benzene ring \\
\hline 1157 & 1151 & 1141 & 1138 & Vibration band of dopant anion \\
\hline 1249 & 1247 & 1249 & 1249 & Secondary $(\mathrm{C}-\mathrm{N})$ stretching band \\
\hline 1313 & 1307 & 1303 & 1305 & Aromatic C-N stretching band \\
\hline 1502 & 1500 & 1504 & 1502 & Benzinoid ring stretching band \\
\hline 1581 & 1579 & 1587 & 1589 & Quinoid ring stretching band \\
\hline 1693 & 1700 & - & 1700 & Carbonyl $(\mathrm{C}=\mathrm{O}$ ) stretching band \\
\hline 2324 & 2380 & 2380 & 2320 & (NH $^{+}$saturated amine \\
\hline 2810 & 2787 & 2891 & 2877 & Aliphatic C-H stretching freq. \\
\hline 3005 & 3080 & 3030 & 3010 & C-H aromatic stretching band \\
\hline 3220 & 3240 & 3190 & 3227 & N-H stretching band \\
\hline
\end{tabular}

Table 2

Conductivity values of lactic acid and acrylic doped polyaniline

\begin{tabular}{|l|c|c|}
\hline \multicolumn{1}{|c|}{ Species } & $\begin{array}{c}\text { Conductivity before exposing } \\
\text { to ammonia vapors, } \mathrm{S} \cdot \mathrm{cm}^{-1}\end{array}$ & $\begin{array}{c}\text { Conductivity after exposing to } \\
\text { ammonia vapors, } \mathrm{S} \cdot \mathrm{cm}^{-1}\end{array}$ \\
\hline Acrylic acid doped polyaniline & $1.83 \cdot 10^{-6}$ & $1.48 \cdot 10^{-4}$ \\
\hline Lactic acid doped polyaniline & $0.6 \cdot 10^{-6}$ & $0.9 \cdot 10^{-7}$ \\
\hline
\end{tabular}


doped sites and trapped $\mathrm{COOH}$ molecules present in polymer matrix. When exposed to ammonia, some molecules of ammonia are adsorbed while some interact with the anions present in the polymer form of ammonia salt. As a result, there is a loss of anions together with the charge imbalance caused over the polymer chain. These effects are neutralized by the trap $\mathrm{COOH}$ molecules [14], which may occupy free dopant sites, thereby increasing the carrier concentration and, hence, the conductivity. On the contrary, in lactic acid doped polyaniline, the conductivity is seen to decrease upon exposure to ammonia vapors. This is because the ammonia molecules interact with the polymer chains, thereby converting the conducting salts phase of polymer to insulting emeraldin base form.

\section{Conclusions}

During in situ synthesis of polyaniline in the presence of acrylic acid, the acrylic acid is added to the polymer chains as a dopant. In comparison with only acid doped polymer, acrylic acid doped polymer is found to have greater solubility in organic solvents. The conductivity of acrylic acid doped polymer is also greater than that of only acid doped polymer, as observed from the UV-Vis and IR analyses of the polymer.

\section{References}

[1] Roy B., Dutta Gupta M., Bhowmit L. and Ray J.: Synth. Met., 1999, 100, 233.

[2] Gabriel A., Gustavo M., Miras M. and Barbero G.: Synth.Met., 1998; 97; 233.

[3] Mercouri G., Kanatzids K.. et al.: J. Am. Chem. Soc., 2002, 122, 6629.

[4] Ito T., Shirakawa H. and Ilkeda S.: J. Polym. Sci., 1974, 12, 11.

[5] Ataman K. and Gupta N.: Polym. Sci., 1993, 1, 284.
[6] Roth S. and Graupner W.: Synth. Met., 1993, 57, 3626.

[7] Wang Y., Hsu J. and Epstein A.: Synth. Met., 1993, 68, 207.

[8] Mortimer R.: Mater. Chem, 1995, 5, 969.

[9] Bergeron J. and Dao L.: Macromolecules, 1992, 2S, 3332.

[10] Genies E. and Lapkowski M.: Synth. Met., 1988, 24, 61.

[11] Pohl H. and Engelhardt E.: J. Phys. Chem.1962, 66, 2085.

[12] Chabukswar V. and Athawale A.: J. Appl. Polym. Sci., 2001, 79, 1994.

[13] Chabukswar V. and Athawale A.: Chem. \& Chem. Techn., $2008,2,257$.

[14] Chabukswar V., Sable G.: Chem. \& Chem. Techn., 2009, 3, 95.

\section{СИНТЕЗ І ХАРАКТЕРИСТИКА ОРГАНІЧНО РОЗЧИННИХ І ЕЛЕКТРОПРОВІДНИХ КИСЛОТ - ДОДАТКІВ ПОЛІАНІЛІНУ}

\begin{abstract}
Анотація. Хімічною оксидаційною полімеризацією синтезовано емералдінову сіль поліаніліну, яка розчинясться у відомих органічних розчинниках. Отримані результати застосовано до поліаніліну з додатками молочної кислоти. Встановлено, щчо поліанілін з додатками акрилової кислоти розчинясться у таких відомих органічних розчинниках, як мкрезол, НМП (N-метилпірролідон), ДМСО, ДМФА, та ін., значно краще, ніж з додатками молочної кислоти. Полімер з додатками акрилової кислоти, приготований з використанням молочної кислоти, краще розчинний в м-крезолі та НМП ніж поліанілін без акрилової кислоти. Вища довжина хвиль з гострим піком в УФ-спектрі для поліаніліну з додатками акрилової кислоти свідчать про його випадкову конформачію. Це вказує на те, що провідність поліаніліну з додатками акрилової кислоти є вищою, ніж у поліаніліну без акрилової кислоти. Широкі та інтенсивні смуги при $3400-3300 \mathrm{~cm}^{-1}$ (N-H коливання) i 1120-1225 $\mathrm{cm}^{-1}$ відповідають за вищий ступінь активації та протонування $\mathrm{N}$-атома амінів та імінів. Ці результати добре узгоджуються з вимірюваннями провідності - провідність поліаніліну з додатками акрилової кислоти є вищою, ніж у випадку без неї.
\end{abstract}

Ключові слова: поліанілін, розчинність, провідність, акрилова кислота. 